\title{
Corrigendum to "PPARs in Human Neuroepithelial Tumors: PPAR Ligands as Anticancer Therapies for the Most Common Human Neuroepithelial Tumors"
}

\author{
Elisabetta Benedetti $\mathbb{D}^{1},{ }^{1}$ Renato Galzio, ${ }^{2}$ Barbara D'Angelo, \\ Maria Paola Cerù, ${ }^{1}$ and Annamaria Cimini $\mathbb{D}^{1}$ \\ ${ }^{1}$ Department of Basic and Applied Biology, University of L'Aquila, 67100 L'Aquila, Italy \\ ${ }^{2}$ Department of Health Sciences (Neurosurgery), University of L'Aquila, 67100 L'Aquila, Italy \\ Correspondence should be addressed to Annamaria Cimini; annamaria.cimini@univaq.it \\ Received 18 June 2019; Accepted 20 June 2019; Published 21 July 2019
}

Copyright (C) 2019 Elisabetta Benedetti et al. This is an open access article distributed under the Creative Commons Attribution License, which permits unrestricted use, distribution, and reproduction in any medium, provided the original work is properly cited.

The article titled "PPARs in Human Neuroepithelial Tumors: PPAR Ligands as Anticancer Therapies for the Most Common Human Neuroepithelial Tumors" [1] was found to contain material in Sections 1, 2, and 3 from published work and to have missing attributions and errors in citations. The articles are as follows:

(i) M. T. Heneka and G. E. Landreth, "PPARs in the brain," Biochimica et Biophysica Acta, vol. 1771, no. 8, pp. 1031-1045, 2007. https://doi.org/10.1016\%2f.bbalip .2007.04.016. [2] (Cited as reference [36]).

(ii) Lars Tatenhorst, Eric Hahnen, and Michael T. Heneka, "Peroxisome Proliferator-Activated Receptors (PPARs) as Potential Inducers of Antineoplastic Effects in CNS Tumors," PPAR Research, vol. 2008, Article ID 204514, 9 pages, 2008. https://doi.org/ 10.1155/2008/204514. [3] (not cited).

(iii) Markus P. Kummer and Michael T. Heneka, "PPARs in Alzheimer's Disease," PPAR Research, vol. 2008, Article ID 403896, 8 pages, 2008. https://doi.org/ 10.1155/2008/403896. [4] (not cited).

(iv) J. N. Feige, L. Gelman, L. Michalik, B. Desvergne, and W. Wahli, "From molecular action to physiological outputs: peroxisome proliferatoractivated receptors are nuclear receptors at the crossroads of key cellular functions," Progress in
Lipid Research, vol. 45, no. 2, pp. 120-159, 2006. https://doi.org/10.1016\%2f.plipres.2005.12.002. (cited as reference [30]).

(v) A. Cimini, E. Benedetti, L. Cristiano et al., "Expression of peroxisome proliferator-activated receptors (PPARs) and retinoic acid receptors (RXRs) in rat cortical neurons," Neuroscience, vol. 130, no. 2, pp. 325-337, 2005. https://doi.org/10.1016\%2fj.neuroscience.2004.09.043. [6] (cited as reference [81]).

\section{References}

[1] E. Benedetti, R. Galzio, B. D’Angelo, M. P. Cer, and A. Cimini, "PPARs in human neuroepithelial tumors: PPAR ligands as anticancer therapies for the most common human neuroepithelial tumors," PPAR Research, vol. 2010, Article ID 427401, 9 pages, 2010.

[2] M. T. Heneka and G. E. Landreth, "PPARs in the brain," Biochimica et Biophysica Acta (BBA)-Molecular and Cell Biology of Lipids, vol. 1771, no. 8, pp. 1031-1045, 2007.

[3] L. Tatenhorst, E. Hahnen, and M. T. Heneka, "Peroxisome proliferator-activated receptors (PPARs) as potential inducers of antineoplastic effects in CNS tumors," PPAR Research, vol. 2008, Article ID 204514, 9 pages, 2008.

[4] M. P. Kummer and M. T. Heneka, "PPARs in alzheimer's disease," PPAR Research, vol. 2008, Article ID 403896, 8 pages, 2008. 
[5] J. N. Feige, L. Gelman, L. Michalik, B. Desvergne, and W. Wahli, "From molecular action to physiological outputs: peroxisome proliferator-activated receptors are nuclear receptors at the crossroads of key cellular functions," Progress in Lipid Research, vol. 45, no. 2, pp. 120-159, 2006.

[6] A. Cimini, E. Benedetti, L. Cristiano et al., "Expression of peroxisome proliferator-activated receptors (PPARs) and retinoic acid receptors (RXRs) in rat cortical neurons," Neuroscience, vol. 130, no. 2, pp. 325-337, 2005. 


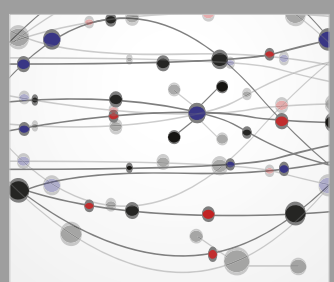

The Scientific World Journal
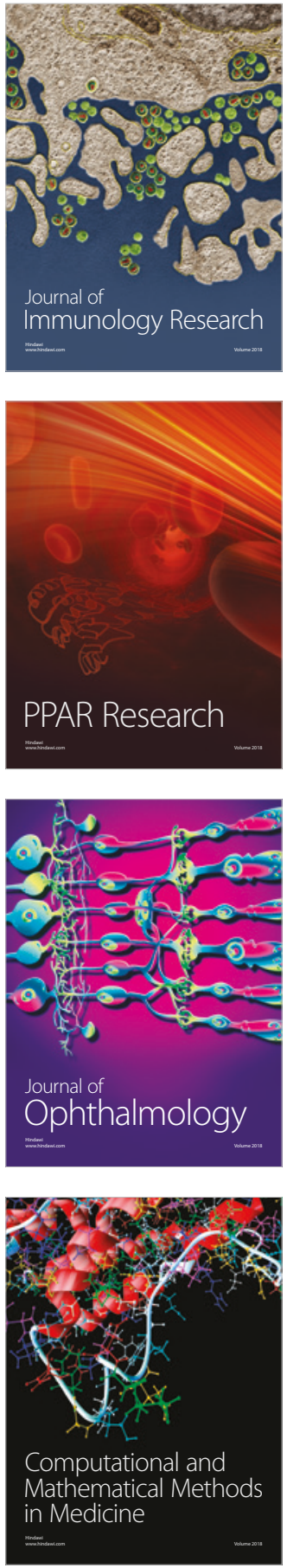

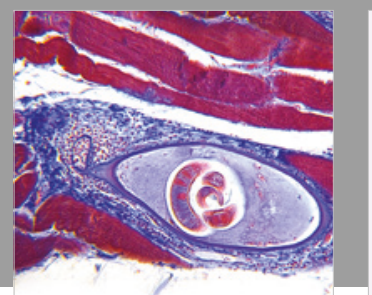

Gastroenterology Research and Practice

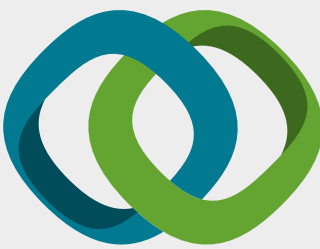

\section{Hindawi}

Submit your manuscripts at

www.hindawi.com
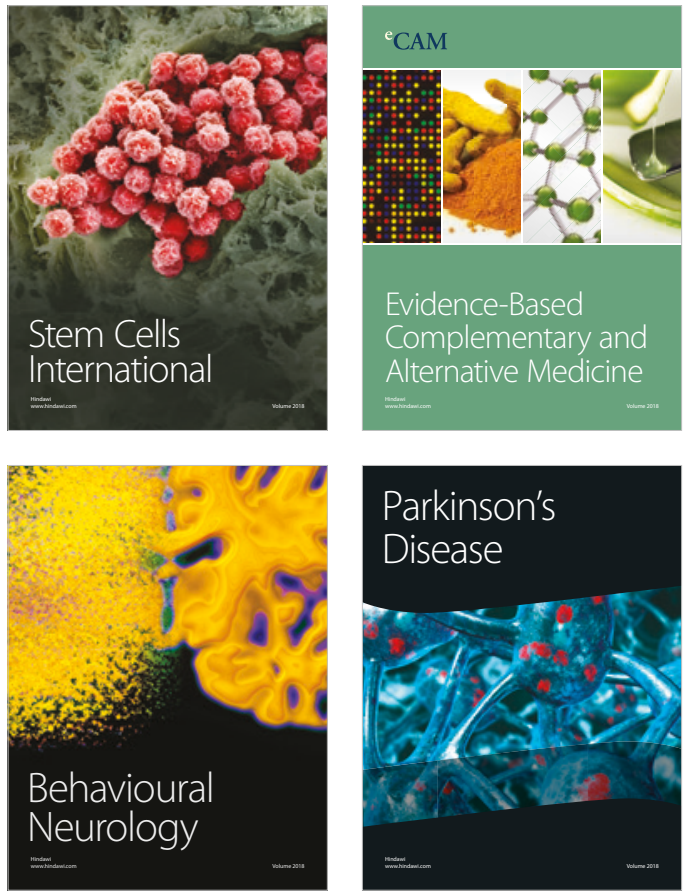

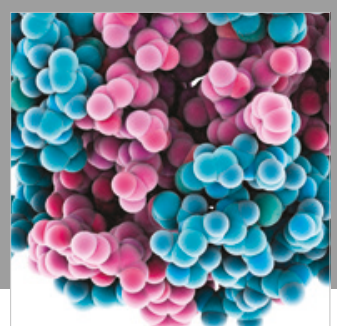

ournal of

Diabetes Research

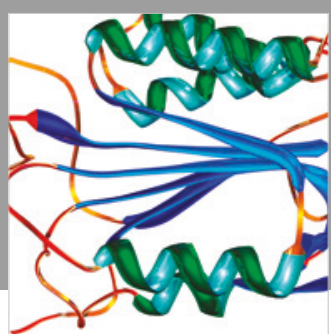

Disease Markers
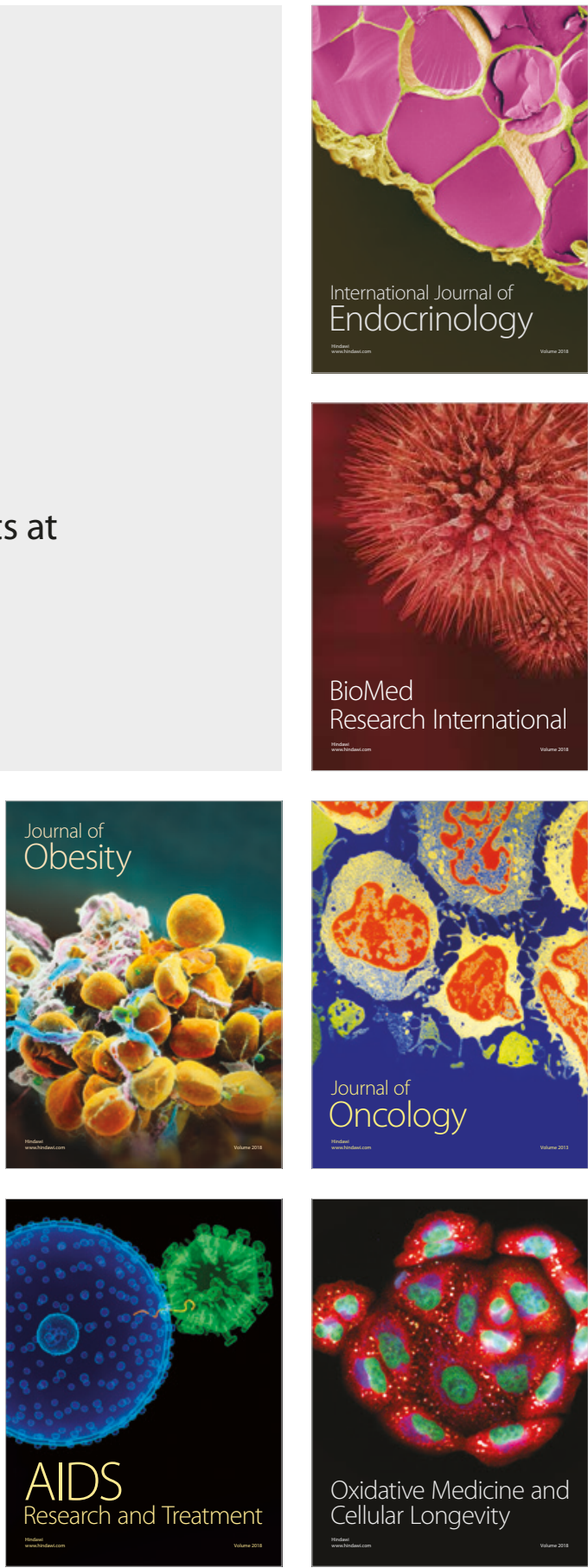